\title{
PHILOSOPHER AND PEDAGOGUE OF CULTURE SERGEI GESSEN AND THE IDEA OF THE UNIVERSITY
}

\section{[FILOSOF A PEDAGOG KULTURY SERGEJ HESSEN A IDEA UNIVERZITY]}

\author{
Jitka Lorenzova
}

doi: 10.18355/PG.2022.11.1.2

\begin{abstract}
This analytical study is dedicated to notable Russian philosopher in exile and theoretical pedagogue of culture Sergei Iosifovich Gessen (1887-1950), who is a somewhat forgotten personality in Czech pedagogy today. It aims to elaborate on those of Hessen's ideas which are at the heart of his concept of pedagogy and of the university as an institution, and which can provide an important frame of reference for the criticism of today's instrumental approach to education and university reform. Gessen is presented as an everinspiring, timeless thinker who developed his philosophical anthropology and general theory of education on the principles of neo-Kantian critical philosophy, and as a representative of humanist educational ideals. The analysis is supplemented by a contradictory perception of Gessen's legacy in the Czech pedagogical environment, which has been negatively impacted by the social and political conflicts of the 20th century. The study employs theoretical analysis of primary and secondary sources, as well as hermeneutic-interpretive methods.
\end{abstract}

\section{Key words}

Sergei Iosifovich Gessen, philosophy of education, pedagogy of culture, NeoKantianism, values in education, university idea

\begin{abstract}
Anotace
Analytická studie je věnována ruskému exilovému filozofovi a teoretikovi pedagogiky kultury Sergeji Josifovičovi Hessenovi (1887-1950), který je v českém pedagogickém prostředí pozapomenutou osobností. Cílem je připomenout ty $\mathrm{z}$ Hessenových idejí, které stojí $\mathrm{v}$ jádru jeho pojetí pedagogiky a univerzity a které jsou i dnes důležitým referenčním rámcem kritiky instrumentálního pojetí vzdělávání a reformy univerzity. Hessen je představen jako stále inspirativní nadčasový myslitel, který rozvinul svou filozofickou antropologii a obecnou teorii výchovy na principech novokantovské kritické filozofie, a jako zastánce humanitního vzdělávacího ideálu. Analýza problematiky je doplněna o ideově rozporné vnímání Hessenova díla $\mathrm{v}$ českém pedagogickém prostředí, na které měly negativní vliv společenské a politické konflikty 20. století. Studie se opírá o metody teoretické analýzy primárních a sekundárních zdrojů a metody hermeneuticko-interepretativní.
\end{abstract}




\section{Klíčová slova}

Sergej Josifovič Hessen, filozofie výchovy, pedagogika kultury, novokantovství, hodnoty ve výchově, idea univerzity

\section{Úvod - cíl a metody studie}

Mnohostranný ruský filozof, pedagog kultury, teoretik právního státu a publicista Sergej Josifovič Hessen (1887-1950), je v českém pedagogickém prostředí pozapomenutou osobností, přestože za svého pobytu v meziválečném Československu dosáhl značného uznání. Svoji filozofickou antropologii a obecnou teorii výchovy rozvíjel na principech novokantovské kritické filozofie a z této onto-gnozeologické perspektivy dospěl k ucelenému systému výchovy. Byl historicky prvním myslitelem, který v ruské filozofii studoval pedagogické otázky (Grebeshev \& Nizhnikov, 2016). V důrazu na sociální aspekt výchovy a v sympatiích k právnímu socialismu je u Hessena patrný také vliv P. Natorpa, představitele marburského novokantovství, zakladatele filozoficky pojaté sociální pedagogiky. Historičnost Hessenova př́stupu nalezla inspiraci v hermeneutice W. Diltheye.

Cílem studie je připomenout ty z Hessenových idejí, které stojí v jádru jeho pojetí pedagogiky a univerzity a které jsou i dnes důležitým referenčním rámcem kritiky instrumentálního pojetí vzdělávání a reformy univerzity. Pozornost je zaměřena na období Hessenova československého exilu, kdy se završuje jeho pedagogické myšlení v syntetickém díle Filosofické základy výchovy. Celkový obraz problematiky je doplněn o ideově rozporné vnímání Hessenova díla v českém pedagogickém prostředí, které odráží společenské a politické konflikty 20. století. Studie má teoretický charakter, opírá se o metody teoretické analýzy primárních a sekundárních zdrojů a metody hermeneuticko-interpretativní.

\section{K životu a dílu S. Hessena s akcentem na jeho působení $\mathrm{v}$ československém exilu}

S. Hessen byl ve své době významným představitelem novokantovství, které se jako filozofický směr začalo prosazovat v Rusku již koncem 19. století. Jeho prvním významným vyznavačem byl profesor Petrohradské univerzity, filozof a psycholog Alexandr Vveděnskij (1856-1925), pod jehož jeho osobním a vědeckým vlivem objevili mladí ruští intelektuálové Kanta a jeho následovníky (Dmitrieva, 2016, pp. 23-24) ${ }^{1}$. Kromě vlivu Vveděnského přispěla $\mathrm{v}$ Rusku k prosazení uvedeného směru i relativně krátká filozofická tradice a nezralost domácích intelektuálních poměrů (tamtéž), která nutila adepty filozofie odcházet za studii do zahraničí, mimo jiné na univerzity $\mathrm{v}$ Heidelbergu a Freiburgu, kde působili predstavitelé bádenského novokantovstí, W. Windelband a H. Rickert. Není bez zajímavosti, že ze

\footnotetext{
${ }^{1}$ Kromě Hessena k nim patřili (Dmitrieva, 2016): Ivan Lapšin (1870-1952), Alexander Veideman (1879-1943), Nikolaj Boldyrev (1883-1929), Nicolaj von Bubnoff (1880-1962), Jacob Gordin (1896-1947), Bogdan Kistiakovskij (1868-1920), Vasilij Seseman (1884-1963), Gavriil Gordon (1885-1942), Leonid Gavrilovič (1878-1953), Ivan Iljin (1883-1954), Matvei Rubinstein (1878-1953), Henry Lanz (1886-1945).
} 
stejných důvodů jako mladí Rusové procházeli podobným formativním procesem i jejich španělští vrstevníci z tzv. generace $1914^{2}$.

Vliv novokantovství na duchovní klima Evropy byl ve své době značný. Tato axiologicky založená filozofie vyřešila schisma mezi vědami empirickými a duchovědnými tím, že každé $\mathrm{z}$ nich přisoudila samostatné domény badatelské působnosti. Podstatu svých noetických předpokladů vyjádřila heslem „příroda existuje, hodnoty platí“. Uznáním svébytné platnosti nadčasových hodnot dokázala úspěšně čelit pozitivismu a novopozitivismu, směrům, které svým požadavkem neutrality vědy přivodily krizi až dosud neotřesitelné metafyzické filozofii. Kritická metoda poznání také nabízela způsob, jak vědecky zdůvodnit právo, politiku i vzdělávání, domény kultury, ve kterých se pohyboval také S. Hessen ${ }^{3}$.

$\mathrm{S}$ bádenským novokantovstvím se Hessen seznámil př́mo u zdroje; filozofii studoval po ukončení práv v Petrohradě na univerzitách ve Freiburgu a Heidelbergu. V roce 1909 publikoval v Berlíně disertační práci Individuelle Kausalität: Studien zum transzendentalen Empirismus (Individuální kauzalita: Studie transcendentálního empirismu). Po návratu do Ruska vyučoval na univerzitách $\mathrm{v}$ Petrohradě a Tomsku, působil v ruské redakci mezinárodního vědeckého časopisu Logos, který byl vydáván mezi léty 1910-1914 v úzké spolupráci ruských a německých novokantovců. Redakce kolem sebe soustředila zejména prríznivce bádenské školy, kam patřili kromě S. Hessena také Fjodor Stepun a Boris Jakovenko (Grebeshev \& Nizhnikov, 2016).

Do životních osudů S. Hessena následně zasáhly dramatické události 20. století. Po bolševické revoluci došlo v Rusku k pronásledování intelektuálů a filozofie, tento ryzí projev svobody lidského ducha, se stala nebezpečím pro nový sovětský režim - bylo zakázáno šírit dokonce i takové filozofy, jako byli Platon, Descartes, Kant, Schopenhauer, Hume, přednášky nemohli konat ani ruští filozofové, kteří přijali marxismus, ba ani staří marxističtí filozofové (Mach, 2012). Řada ruských intelektuálů volila emigraci a mnohým z nich se novým domovem stalo mladé demokratické Československo.

Filozofickou diasporu ruské emigrace v ČSR tvořily tři hlavní skupiny (Mach, 2012, p. 125): Do první patřila druhá generace petrohradského novokantovství, filozofové N. O. Losskij a I. I. Lapšin (žáci Vvedenského). Další skupinu tvořila třetí generace petrohradské školy, reprezentovaná S. I. Hessenem a B. V. Jakovenkem. Do třetí náleželi tzv. eurasijci, představitelé specifické větvě ruské politické filozofie a filozofie dějin, kteří věřili $\mathrm{v}$ kulturní jednotu tzv. Eurasie, geografického prostoru, na kterém se rozkládalo i tehdejší Rusko. Patřili k nim P. N. Savickij, N. N. Alexejev, G. V. Vernadskij.

\footnotetext{
${ }^{2}$ José Ortega y Gasset, Fernando de los Ríos, María de Maeztu, Lorenzo Luzuriaga a další (více k tomu Lorenzová, 2017).

${ }^{3}$ První novokantovskou školu orientovanou na filozofii práva založil na Katedře práva Státní moskevské univerzity Pavel Novgorodtsev (1866-1924), druhá škola, zaměřená na metodologii historie, se zformovala kolem historicko-filozofického semináre vedeného historikem a filosofem Alexandrem Lappo-Danilevským (1863-1919) na Státní univerzitě v Petrohradě (Dmitrieva, 2016, s. 25).
} 
Hessenovo československé období (1923-1934) lze charakterizovat jako velmi činorodé a plodné. Vyučoval na Ruském pedagogickém institutu, Ruské národní univerzitě (někdy uváděno též jako Ruská svobodná či lidová univerzita) a konečně také od 30. let na Německé univerzitě v Praze. Byl mj. členem Archeologického ústavu N.P. Kondakova, Slovanské společnosti při Německé univerzitě v Praze, Pražského lingvistického kroužku, Společnosti F.M. Dostojevského, členem a poté i předsedou Svazu ruských spisovatelů a novinářu $\mathrm{v}$ Československu. Působil jako redaktor $\mathrm{v}$ Praze vydávaného časopisu Ruská škola v zahraničí (Russkaja škola za rubežom), ve své době jediného ruskojazyčného čistě pedagogického časopisu vydávaného mimo území Ruska. Kromě toho se angažoval $\mathrm{v}$ organizování sjezdů ruské pedagogické emigrace.

Hessenovy statě vycházely v tomto období v ČSR i v zahraničí, zejména v ruských exilových časopisech Novyj grad a Sovremennye zapiski (oba vydávané v Pařiži). Jako autor byl nejen plodný, ale také všestranný. Kromě řady pedagogických a filozofických textů publikoval aktuální statě politologické, např. k agrárnímu programům evropských socialistických stran (Hessen, 1928) nebo k politickému směřování nové sociálně demokratické strany Rakouska (Hessen, 1927). Vyjadřoval se také k otázkám ekonomickým, např. k ekonomické krizi kapitalismu, která pro něj byla zároveň krizí klasické ekonomické teorie (Hessen, 1932).

Velmi intenzivně se za svého pobytu v ČSR zabýval filozofíi práva, resp. politicko-sociálními otázkami právního státu. Svébytné místo v tomto proudu jeho tvorby má cyklus statí Problém právního socialismu zveřejňovaný v letech 1926-1928 v pařížském časopise Sovremennyje zapiski. Hlavním poselstvím je konstatování krize klasického liberalismu, který nedokázal prosadit svoji vysoce inspirativní ideu právního státu (vlády práva) v plném rozsahu a zůstal na úrovni utopické vize. $\mathrm{V}$ této věci však ztroskotal i komunismus, který již samotnou konstrukcí svých právních norem ideu práva popírá, když ji chce prosadit zákonem pouze v zájmu jedné skupiny, dělnické tř́́dy (Hessen, 1924). Východiskem ze situace byl pro Hessena právní socialismus jako syntéza liberální a socialistické tradice. Domnívá se (Agaev, Gutorov \& Shirinyans, 2020), že praxe směřuje $\mathrm{k}$ socialismu, sociální myšlence a socializaci.

Problematický charakter utopického myšlení byl pro Hessena zásadní. Riziko viděl zejména $\mathrm{v}$ tom, že utopismus při uvádění svých vizí do praxe destruuje vládu práva a historicko-kulturní sounáležitost generací. K tématu se pro jeho naléhavost vracel opakovaně. Závažná je v tomto kontextu stat' Kolaps utopismu (Krušenije utopizma) z roku 1924, promýšlející vztah utopie k hodnotám kultury. V ní Hessen ukázal, že základní charakteristikou utopismu je nepřátelství vǔči všemu, co bylo historicky zděděno od předchozích generací. Historie není pro utopické myšlení zdrojem poznání,

\footnotetext{
${ }^{4}$ Podle Hessena dospěla racionalizace průmyslu po první světové válce do podoby továrního průmyslového kapitálu, který ztratil schopnost pružně reagovat na tržní výkyvy. To vedlo $\mathrm{k}$ zostření konkurence, depresi některých odvětví a k nezaměstnanosti a postavilo na hlavu klasickou ekonomickou teorii s její představou automatického přizpůsobování kapitálu volnému trhu (Hessen, 1932).
} 
ale nepřetržitá hromada bludů a omylů, jen nadvláda zla, kterou je třeba odstranit (Hessen, 1924, p. 278). Tento nehistorický a obrazoborecký př́stup je rizikem pro kulturu a její hodnoty a v důsledku ohrožuje samotné lidství, které má svoji nezpochybnitelnou dějinnou dimenzi.

Hessen zaujímal také kritická stanoviska k pedagogickým koncepcím a školským reformám realizovaným jak na Západě (Anglii, Francii), tak v sovětském Rusku. V návaznosti na svoje humanistické přesvědčení publikoval v roce 1933 v pařížském časopise ruské křest'anské inteligence Novyj Grad ostře kritickou stat' Osud komunistického ideálu školství (Sudba kommunističeskogo ideala obrazovanija), ve které ukázal principiální prázdnotu sovětské školské reformy. Kritizuje, že původní demokratický ideál transformace sovětského školství a polytechnicky rozvinuté osobnosti svobodně se projevující v beztřídní společnosti byl velmi rychle, již v období Nové ekonomické politiky (NEP), zatlačen do pozadí ideálem „bojovníka za zájmy proletariátu“, který pevně ovládá marxistický světonázor. Na konci NEP (1926-1927) však již i tento ideál „třídní profesionality“ vybledl a vyhasl a školská politika sovětské vlády nabyla rysů bezzásadového oportunismu vedoucího $\mathrm{k}$ obnově prvků staré školy. Komunistický ideál školství je podle Hessena extrémně proměnlivý a nestabilní a pro realitu nepoužitelný. Nejenže nedokázal vytvořit nic pozitivního, ale sám byl rozleptán svou vnitřní negativitou, která je pro komunismus, stejně jako pro každou utopii, typická (Hesssen, 1932).

V oblasti obecné filozofické antropologie a pedagogiky, které jsou primárně předmětem zájmu tohoto článku, prožívá Hessen v Praze období tvưrčí zralosti. Ještě př́ed př́ichodem do pražského prostředí působil rok na univerzitách ve Freiburgu, Jeně a Berlíně, kde publikoval svoje významné pedagogické dílo Základy pedagogiky: Úvod do aplikované pedagogiky (Osnovi pedagogiki: Vvedenije v prikladnuju filosofiju, 1923). Šlo o vysokoškolské přednášky z jeho ruského univerzitního působení. Kniha bez nadsázky zasáhla celý slovanský pedagogický svět. V roce 1929 vyšla v loty̌šstině, 1931 v upraveném polském vydání, 1933 srbsky, bulharsky pak o dva roky později. České vydání bylo paradoxně časově nejvíce opožděno. Provázely ho obtíže s hledáním překladatele a nakladatele. První tři kapitoly nakonec přeložil významný český fenomenologický filozof J. Patočka, žák E. Husserla, ostatní části knihy dr. V. Bezděková. Knihu nakonec vydala v roce 1936, tedy až po Hessenově odchodu do Polska, Česká tiskařská unie. Vyšla pod mírně změněným názvem Filosofické základy pedagogiky. Jádrem textu zůstaly, jak napsal Hessen v předmluvě datované 23.8.1935, přednášky z jeho působení na univerzitách v Tomsku (1918-1920) a Petrohradu (1921). Nicméně podle autora byl text pro české vydání důkladně přepracován a jeho výsledná podoba ze všech vydání knihy nejvíce odpovídá jeho pedagogickým názorům. V následující části textu se těmto názorům budeme věnovat, nejprve obecně v kontextu Hessenovy filozofické antropologie, poté ve vztahu $\mathrm{k}$ teorii univerzity, která je $\mathrm{z}$ našeho pohledu inspirativním nastavením zrcadla současným reformám univerzitního vzdělávání. 


\section{Kultura, hodnoty a filozofie v Hessenově pedagogické koncepci}

Jako př́slušník třetí generace ruského novokantovství vděčil Hessen podle vlastních slov za mnohá zdůvodnění svých pedagogických východisek bádenské škole, zejména W. Rickertovi (Hessen, 1936, p. 10). Právě Rickertův filozofický pojem kultury ve smyslu celku hodnot jako nadosobních ideálních principů se stal jádrem Hessenovy obecné teorie vzdělávání. „Kultura“, konstatuje v první kapitole knihy Filosofické základy výchovy nazvané Problém nauky o výchově, „existuje všude tam, kde si lidstvo klade vědecké, umělecké, právní či hospodářské cíle“. Tyto cíle se kryjí s nadindividuálními hodnotami jako věčnými a neměnnými ideálními principy veškerého lidského snažení, celek těchto hodnot je označován jako kultura. Právě existence hodnot odlišuje kulturního člověka od primitiva (Hessen, 1936, p. 3).

Hodnoty se zásadně liší od jiných cílů tím, že jsou nadčasové a mají účel samy $\mathrm{v}$ sobě. $\mathrm{V}$ lidském žití nemohu nikdy klesnout na úroveň pouhého prostředku. Umění, mravnost věda, náboženství se nevyčerpávají svojí služebnou funkcí (např. věda jako nástroj dosažení hospodářských cílů), nejsou nástroji, které ,ztrácejí svůj význam a mizí spolu s těmi cíli, k jichž dosažení jsou prostředkem" (Hessen, 1936, p. 8). Hodnoty jsou naopak nekonečné a nevyčerpatelné, a $\mathrm{v}$ tomto smyslu jsou pro naplnění smyslu lidského života věčnou inspirací. Nikdy nebude uskutečněn ideál dokonalé krásy, nikdy nebude zcela naplněn ideál povinnosti, nikdy se nevyčerpá úkol vědy poznávat, ale každý splněný úkol a vyřešený problém klade nové cíle a otevírá nové problémy - at' se tedy člověk přibližuje hodnotám sebevíc, zůstávají „úlohami bez rožrešení” (Hessen, 1936, p. 7). Před věčnost těchto úloh je postavena každá generace, která se s nimi musí vždy nově vypořádat. Vztah k hodnotám tak dává náhledu světa vitalitu a zabraňuje, aby se změnil v ideologii nebo v mrtvé abstraktní poznání (Grebeshev \& Nizhnikov, 2016).

$\mathrm{Na}$ rozdíl od bytí kauzálně podmíněného, hodnoty nedonucují člověka jednat určitým způsobem, pouze od něj vyžadují rozhodnutí, při kterém má svobodnou volbu hodnotu přijmout nebo zavrhnout. Platnost hodnoty tedy předpokládá lidskou svobodu a lidská svoboda je výběrem hodnot, při kterém člověk přestupuje hranice daného jsoucna a vytvář́ něco nového (Hessen, 1936, pp. 42-43). „Jsouce povzneseny nad čas a trvajíce v klidu vyžadují kulturní hodnoty na člověku neustálého růstu a pohybu" (Hessen, 1936, p. 10). Jde tedy také u Hessena o platónský archetyp výchovy, který spočívá v obratu duše, kdy jedinec sám v sobě, svým vnitřním duševním zrakem hodnoty rozpoznává jako vyšší typ pravdy. Právě tato náročná duchovní práce je podstatou vzdělávání.

Hodnoty jako věčné úkoly jsou vždy hledanými cíli vzdělávání, toho, co „má být”, a proto duše a tělo dítěte mají být formovány ve směru těchto hodnot. Vzdělání je tedy korelátem kultury. Jde o natolik přesnou korelaci, že musí být tolik druhů vzdělání, kolik je jednotlivých kulturních hodnot - proto lze mluvit o vzdělání mravním, vědeckém (teoretickém), uměleckém, právním, náboženském. Skutečnou podstatu vědy, mravnosti, umění a práva však poznávají filozofické vědy, logika, etika, estetika. Proto je pro Hessena pedagogika, která řeší individuální problém utváření a rozvoje, praktickou aplikací filozofie jako teoretického poznání (Grebeshev \& Nizhnikov, 2016). 
Úlohou filozofie a filozofických věd je odhalovat význam hodnot, které jako celek zakládají kulturu lidstva. Tyto druhy významů (Grebeshev a Nizhnikov, 2016) mohou být samožrejmě nevědomě vnímány i mimo filozofii - umělec se řídí svou intuicí krásy, vědec, používá vědecký aparát, mohou se však mýlit $\mathrm{v}$ chápání vědy a nekriticky opakovat filozofické předsudky. Filozofie je kritická reflexe toho, co je intuitivně a nevědomě známé každému z nás, lidské zkušenosti a lidského sebepoznání. Jako nejvyšší forma humanitní racionality pomáhá překonat determinismus sociálních a historických životních podmínek tím, že podněcuje touhu člověka vztahovat se $\mathrm{k}$ transcendentnímu světu obecně platných hodnot - tato „transcendující osobnost“ je obecný cíl Hessenovy filozofické pedagogiky (Grebeshev \& Nizhnikov, 2016).

\section{Vzdělání jako výchova charakteru}

Kromě novokantovství Hessen pedagogicky čerpá také z německého idealistického novohumanismu a jeho pedagogického ideálu, který ř́íká, že smyslem vzdělání je charakterové utváření jedince. Pro takové pojetí vzdělávání existuje $\mathrm{v}$ němčině výraz Bildung. Klasikem ve vymezení tohoto pojmu byl filozof J. G. Fichte (1762-1814), který v univerzitním přednáškovém cyklu O pojmu člověka (1800) vymezil vzdělání jako individuální kulturu jedince, díky níž jedinec dokáže vykořenit vlastní chybné sklony vzniklé před probuzením rozumu a ovládnout sebe i věci kolem podle pojmů. Cílem je dokonalá autonomie, která znamená podřídit si všechno nerozumné, ovládnout je svobodně a podle svého zákona. Tento naprostý soulad se sebou samým je dokonalost $\mathrm{v}$ nejvy̌šíím významu toho slova (Fichte, 1971[1800]). Jak ale Fichte také upozornil, cíl vzdělání chápaný jako dokonalost je nedosažitelný, a cesta $\mathrm{k}$ němu tedy nekonečná. Posláním člověka proto není tohoto cíle skutečně dosáhnout, ale přibližovat se $\mathrm{k}$ němu $\mathrm{s}$ maximálním vynaložením sil. Toto nekonečné přibližování ideálu ve smyslu lidského a mravního sebezdokonalování je pravým posláním člověka jako svobodné a rozumné bytosti (Fichte, 1971[1800]). S tímto závěrem Hessen naprosto souhlasí. Z hlediska pedagogického má v procesu sebezdokonalování podle Hessena zcela speciální místo mravní výchova, která přivádí dítě, ovládané zpočátku jen vrozeným temperamentem a slepým instinktivním donucením, k sebevýchově a autonomii, a tím otevírá cestu formování osobnosti a charakteru (Hessen, 1936, p. 10).

\section{Škola jako činitel kultury a vychovatel lidskosti}

Hessen celoživotně zůstal věrný humanitnímu vzdělávacímu ideálu, který říká, že utváření osobnosti se uskutečňuje duchovní prací na všelidských cílech. Škola má být schopna vztah mladého jedince $\mathrm{k}$ hodnotám otevírat, uvádět do kultury, ve které se významy hodnoty ukazují. V tomto smyslu je klíčovým vzdělávacím a mravním činitelem ${ }^{5} \mathrm{v}$ rámci národa. Národ však nemá žít uzavřený do své kultury, jeho univerzální působiště je $\mathrm{v}$ rámci celého lidstva. Hessen se tak odpoutává od starší ruské pedagogické tradice,

\footnotetext{
${ }^{5}$ U Hessena odpovídá školský systém třem stadiím mravního vývoje jedince - mateřská škola anomii, základní a střední škola heteronomii, univerzita autonomii.
} 
když problematizuje K. D. Ušinského, který říká, že každý národ má svoji neměnnou duši, esenci. Duše národa podle Hessena však nespočívá ve specifičnosti jeho kulturních a psychologický znaků. Naopak, jedinec i národ se jen potud stávají nezaměnitelnými individualitami, pokud uskutečňují hodnoty všelidské (Hessen, 1936, p. 330).

Lidstvo také není souborem jednotlivců, ale duchovním „spojením generací již vymřelých, které dál žijí ve svých dílech zachovaných dějinami, $\mathrm{s}$ generacemi ještě nenarozenými, které jsou ale již počaty $\mathrm{v}$ úkolech doby přítomné“ (Hessen, 1936, p. 168). V této duchovní kontinuitě generací vzniká společná kulturní půda jako předpoklad porozumění a sebeporozumění. Hessen se v tomto smyslu argumentačně obrací i k Masarykovi: „Lidstvo v pravém smyslu je humanita jako jednota skutků a úkolů téhož nekonečného proudu tvoření, projevujícího se v dějinách. Toto Masarykovo pojetí lidstva jako humanity (...) je jedině správné“ (Hessen, 1936, p. 168). Z uvedeného je zřejmé, že přenos hodnot není žádným mechanickým bezduchým aktem, tak typickým pro starou školu, ale ze samé podstaty tvưrčím procesem. Ve škole se stává otázkou individuálního utváření prostřednictvím kontaktu dětské duše s duchovními kulturními obsahy.

\section{Hessenův náhled na vývoj univerzity}

Můžeme vytknout před závorku, že Hessen byl jako zastánce humanitního pojetí vzdělanosti zastáncem klasické univerzitní tradice. Je to patrné i z přehledu děl, na kterých založil 12. kapitolu Filosofických základů výchovy, nazvanou Stupeň vědeckého běhu - Theorie university. V tomto systematickém pojednání vychází zejména z německých osvícenských a novohumanistických autorů. V přehledu je uveden I. Kant (Der Streit der Fakultäten, 1798), F. Schelling (Vorlesungen über die Methode des akademischen Studium, 1803), J. G. Fichte (Deduzierter Plan einer zu Berlin zu errichtenden höheren Lehranstalt, die in gehöriger Verbindung mit einer Akademie, 1807; Über die einzig mögliche Störung der akademischen Freiheit, 1810), F. Schleiermacher (Gelegentliche Gedanken über Universitäten in deutschem Sinn, 1808), H. Steffens (Über die Idee der Universitäten, 1809) a samožrejmě, W. Von Humboldt (Über die innere und äussere Organisation der höheren wissenschaftlichen Anstalten in Berlin, 1810). Tyto klasické texty Hessen doplnil dílem ve své době nejnovějším, Jaspersovou Ideou univerzity (Die Idee der Universität, vydání z roku 1933) a dále pak značným množstvím výkladové vědecké a pramenné literatury $\mathrm{k}$ historii a vývoji univerzit německých, francouzských, amerických, ruských a českých.

Univerzita jako instituce vědy a poznání má v Hessenově pedagogickém systému výlučné postavení. V jeho době již šlo o relativně zformovanou vědeckou instituci, která měla za sebou několik stovek let vývoje. Po značnou část své existence byla chápána jako „společenství těch, kteří se věnují odhalování, zprostředkování a osvojování nesčetných zlomků univerza metodicky poznávaných pravd“ (Lobkowic, 1993, p. 58). Hessen ji také tak vykládá: Ve středověku slovo „universita“ původně znamenalo korporaci, cech studujících nebo vyučujících - universitas scholarum et doctorum (Hessen, 1936, s. 295). Univerzity byly stavovsky odborné školy, jejichž 
organizace odpovídala třem hlavním typům svobodných povolání, kněze, právníka a lékaře. $\mathrm{V}$ tomto duchu sestávala univerzita ze tří vyšších fakult, teologické, právnické a lékařské, pro které připravovala fakulta svobodných umění (Hessen, 1936, p. 299) ${ }^{6}$. Po reformaci (Hessen, 1936, p. 315) přešlo právo zřizovat univerzity do rukou státní moci, která je podřídila své výlučné kontrole, s výjimkou Anglie, kde si zachovaly charakter korporací a jejich zřizování přešlo na parlament. Univerzity tak postupně ztratily dávná privilegia i znaky obecných studií.

Nejpozději od renesance a E. Rotterdamského získalo slovo univerzita ještě další význam, celek vědeckého poznání (universitas scientarium), znamenalo tedy daleko spíše než společenství lidí „organickou celistvost vědy samé“ (Hessen, 1936, p. 295). Zároveň rostl význam filosofické fakulty a postupně zmizel i její průpravný charakter - kvadrivium (aritmetika, geometrie, astronomie, muzika), původně přípravný směr formálněmatematický, se po objevech Descartových, Newtonových, Galileových a Keplerových rozvinul do metody matematické prrírodovědy, obohacované látkou prírodních věd. Trivium (gramatika, rétorika a logika), původně formálně-logický př́ípravný směr, se rozvinul pod vlivem humanismu a novohumanismu k metodě filologického poznání, obohacované od počátku 19. století látkou historických věd. V souladu s tím rostl význam filozofie, která se stála základní disciplínou filozofické fakulty (Hessen, 1936, p. 299).

Pod vlivem racionalismu osvícenství se také stále více prosazovala myšlenka, že univerzity by měly vzdělávat prostřednictvím vědy (Petráň, 1993, p. 102). Ovšem s tím, jak neustále rostl význam odborného vzdělávání, se univerzity začaly měnit spíše $\mathrm{v}$ jakési př́pravky $\mathrm{k}$ povolání, často instruktážního typu. Z univerzity se tak vytratila její původní idea, svobodně bádat a předávat celek vědy (Palouš, Šabatová \& Štern, 1993, p. 84). Takové pojetí vyššího vzdělávání si vysloužilo kritiku od pozdějšího reformátora pruské univerzity, filozofa, př́rodovědce a jazykovědce, W. von Humboldta (1767-1835). Ten ve své době napsal: „Věčná examina přivádějí posluchače k zoufalství, vyvolávají nepřekonatelný odpor k vyučování, vzbuzují nechut' $\mathrm{k}$ vědomostem, které jsou do hlav nalévány, dusí žádostivost po vědění" (Humboldt in tamtéž, s. 84). Humboldt se proto rozhodl vrátit k původnímu ideálu univerzitního vzdělávání, integrálnímu spojení bádání a výuky jako universitas litterarum, celku veškerého vědění (Petráň, 1993, p. 102). Reforma byla provedena podle Humboldtova Organizačního plánu nejdřive na univerzitě v Berlíně (1809), poté v Bonu, Mnichově a Vratislavi a postupně se prosadila $v$ celém duchovním prostoru Evropy, od Německa přes Rakousko a Francii po Itálii, Anglii a Skotsko. Hessen toto pojetí univerzity tvưrčím způsobem integroval do svého pedagogického systému.

\footnotetext{
${ }^{6}$ Tyto světské korporace se ve středověké Evropě svěřovaly do moci papeže, aby získaly status obecných studií (studia generale) a s ním spojené další výsady, jako byla nezávislost na světské moci, svoboda duchovní (libertas spiritus), svoboda vyučování (liberats scholastica), právo promovat, jmenovat profesory a volit ze svého středu rektora (Petráń, 1993).
} 


\section{Humboldtova reforma jako zdroj kritické reflexe Hessenova pojetí univerzity}

Pokud měla univerzita předávat celek vědy, bylo třeba dát všem speciálním vědám univerzální vědeckou metodu a uvést jejich poznatky do náležitých vztahů (Dubský, 1993, p. 75). Tento úkol připadl v rámci Humboldtovy reformy filozofii. Jestliže sjednocujícím činitelem univerzity středověké byla duchovní jednota západního křest'anství, $\mathrm{k}$ odkazu Humboldtovy reformy patřila představa o filozofičnosti každé vědy, nebot' každá jednotlivá věda existuje jen ve vztahu k celku vědeckého poznání vi̊bec (Jaspers, 1923). Jen filozofie v jejím pojetí čisté vědy byla schopna osvobodit lidského ducha od omezenosti jednostranného vzdělání a pozvednout ho do řiše nad-individuálního a principiálního vědění (Dubský, 1993, s. 75). Právě v tomto duchu podř́dil Humboldtův organizační plán studium všech speciálních věd studiu filozofie. Filozofická fakulta se tak stává ústřední fakultou univerzity, nebot' v sobě slučuje vědeckou sílu celé univerzity tím, že oplodňuje duchem čistého (teoretického) poznání i fakulty praktické (Hessen, 1936, p. 299). ${ }^{7}$

Humboldtova reforma stála na silných filozoficko-antropologických předpokladech. Propojila novohumanismus s jeho výchovným ideálem všeobecné lidské vzdělanosti (Goethe, Schiller, Humboldt) s idejemi spekulativní německé filozofie (Fichte, Schelling, Schleiermacher) v jejím pojetí vnitřně propojeného celku vědy a pravdy (Dubský, 1993, p. 74). Nicméně, navzdory snaze novohumanistů postulovat filozofii jako sjednocující meta-rámec věd, samotné vědy směřovaly ke stále větší specializaci, aniž by braly ohled na jejich téměř zbožné přání. A dlužno říci, že ani samotná filozofie německého idealismu nezvládla pojmout do svého celku stále se rozšiřující okruh poznání věd přírodních - začalo se tak ukazovat, že myšlenka identity vědy a vzdělanosti není aplikovatelná na jiné koncepce vědy a vědeckosti (Dubský, pp. 78-79). Právě $\mathrm{z}$ této epistemologické bídy měl filozofii vyvést novokantovský „návrat ke Kantovi“ a jeho kritické metodě poznání, oproštěné od metafyzické spekulace. Hessen tuto metodu aplikoval na celý svůj pedagogický systém, teorie univerzity nebyla výjimkou.

\section{Vědecký úkol a principy univerzity}

Hessen rozvíjel teorii univerzity $\mathrm{v}$ době, kdy se po bolševické revoluci $\mathrm{v}$ Rusku a později po politickém nástupu nacismu v Německu začalo ukazovat, že univerzita není ani zdaleka tak svobodný a autonomní živoucí organismus vědy, jak si žádala její historicky vzniklá idea. A přesto (nebo právě proto), se obhajoby této ideje Hessen z kritických novokantovských pozic ujímá.

Univerzitu považuje zcela $\mathrm{v}$ intencích Humboldtových za spíše vědecké než pouze školské pracoviště. Proto je základním úkolem univerzity nikoli

\footnotetext{
${ }^{7}$ Hessen již jen připomíná, že v procesu emancipace filozofické fakulty sehrál klíčovou roli Kant, který se pokusil obhájit její postavení v rámci univerzity ve spisku Streit der Fakultäten (1798). Lze tedy ř́ci, že v Hessenových očích Humboldtova reforma tuto Kantovu snahu jen završila.
} 
předávat poznatky, ale zasvětit studenty do metody vědeckého myšlení (Hessen, 1936, p. 290). ${ }^{8}$ Osvojit si metodu znamená být schopen činného poznání a zvládnout umění poznání užívat (Hessen, 1936, p. 257). Toto osvojení metody je podstatou vědeckého vzdělání, které poskytuje univerzita. Samo vědecké vzdělávání je velmi dlouhý proces, který se na univerzitě sice završuje, musí mu však předcházet etapy, které jedince na přijetí vědecké metody připraví. Tyto etapy probíhají na nižších vzdělávacích stupních. Hessen hovoří o etapě epizodické, která se realizuje na škole primární, a etapě systematické, která př́śluší vzdělání sekundárnímu. Na ně navazuje etapa vědecká, uskutečňovaná na univerzitě. Hessen tyto etapy nestanovuje, tak jak bylo populární $\mathrm{v}$ tehdejším pedagogickém reformismu, psychologicky, ale reflexivně, tj. filozoficky, na základě logické analýzy cíle vědeckého vzdělávání. Tím je, jak již bylo řečeno, osvojení metody vědeckého myšlení. Vzhledem $\mathrm{k}$ tomu, že idea vědeckosti je úhelným kamenem Hessenova systému, stručně tyto fáze představíme.

Vzdělání epizodické (Hessen, 1936, pp. 261-262) uvádí do vědeckého poznání tak, že vybírá jako vzdělávací obsahy „epizody“, které souvisejí $\mathrm{s}$ bezprostředním okolím dítěte, $\mathrm{s}$ tím, co je dítěti svým životním významem srozumitelné, co má pro dítě pragmatickou hodnotu. Nicméně, ve vzdělávání se má každá epizoda přerodit v problém, aby byla podnícena snaha dítěte $\mathrm{o}$ vysvětlení jevu. Právě toto „zažití problému” vyvolá čistý zájem o poznání věci. A protože cílem vzdělání je $\mathrm{v}$ konečné fázi dospět $\mathrm{k}$ vědecké metodě, nemají být epizody vybrány nahodile, naopak, žák má „pocítit” v pozadí epizody vědecký systém, který ji má prozařovat jako problém předložený jeho poznávací činnosti (Hessen, 1936, p. 263). Analýzou epizod, které dítě zajímají zpočátku jen jako činnou bytost, nikoli bytost poznávající, je dítě vedeno $\mathrm{k}$ uvědomění základních prvků, ze kterých se skládají všechny tyto epizody. Tím jsou mu nejen otevřeny vědecké problémy obsažené $\mathrm{v}$ jeho vlastním prostředí, ale také je připraveno pro přijetí systematičtějšího poznání na vyšších stupních vzdělání (Hessen, 1936, p. 263).

Smyslem systematické vzdělávací fáze je utřídit látku, kterou žák již ovládá, vnést do ní jednotu a souvislost. Vzdělávání v této fázi již probíhá $\mathrm{v}$ souladu se systémem každé vědy, jejími axiomaty, zákony a fakty. Systematický vzdělávací běh tak kompletuje a prohlubuje předchozí poznání a usiluje o to, aby každá věda byla vyložena jako celek (Hessen, 936, pp. 276-277). Systém ale není posledním útvarem ve vědě, nad ním stojí vědecká metoda, která systémem prostupuje jako jeho univerzální princip. Cílem je, „aby žáci vycítili, že za systémem existuje metoda, a ukázat jim, jak se jí v rámci daného systému užívá" (Hessen, 1936, p. 292).

Je-li epizodické vzdělávání prŕípravné vůči vzdělávání systematickému, je systematické vzdělávání přípravné vůči vědeckému. Vědecké vzdělávání je realizováno na univerzitě. Univerzita není škola, která předává hotové systémy vědy, je to $\mathrm{v}$ první řadě vědecká instituce. Věda ve svém „krystalicky čistém stavu“ musí být vždy podávána jako problém, jako něco, co neustále podléhá procesu bádání. Proto vše, co již „ztuhlo” v podobě

\footnotetext{
${ }^{8}$ Naukou o metodě, o tomto „světle vědění”, je pro Hessena v souladu s novokantovstvím logika, kterou ale již nechápe jako čistě formální vědou, ale spiše jako noetikou, tedy jako vědu vysvětlující vnitřní strukturu poznání v její celistvosti.
} 
vědeckého systému, je na univerzitě vždy znovu kriticky přezkoumáváno (Hessen,1936, p. 295). Univerzita tímto způsobem učí otevřenosti viči hledání pravdivého poznání, a proto musí zůstat věrna humboldtovskému ideálu čisté, svobodné vědy. $Z$ toho základního axiomu jsou odvozeny další principy univerzitní instituce. Předně z něj plyne svoboda výuky a studia (Lehr-und Lernfreiheit).

Svoboda výuky a studia nemůže být ničím svázána, žádným hotovým vědeckým systémem, ani ničím vnějším, například organizací studia a vyučování. Dokonce (a to je nepochybně pro nás, pedagogy, náročné přijmout) ani žádnou vysokoškolskou didaktikou. Pokud se totiž na vysoké škole kryje vyučování s bádáním o pravdě, potud metodika výuky musí být založena na metodologii vědy, nikoli na didaktice. Jedinou a dostačující kvalifikací vysokoškolského pedagoga je proto kvalita jeho vědecké práce. Student pak není žák, který se pouze učí, ale studiosus, ten, kdo se zabývá vědou. Oba společně jsou duší univerzity, protože „pohánějí vědu“ (Hessen, 1936, pp. 292-294).

Ze svobodné podstaty univerzitního bádání, které nesmí být ve vědeckém pojetí podřizeno žádným služebným účelům, plynou u Hessena tři další ideální principy univerzity: jednota vědy a výuky, úplnost vědeckého poznání, autonomie univerzity (korporativní samospráva) (Hessen, 1936, p. 298).

\section{Jednota vědy a výuky}

Jak již bylo řečeno, cílem univerzitního vzdělání je osvojit si metodu vědeckého myšlení. Této metodě se nedá naučit jinak než jejím užíváním. $Z$ toho plyne, že na vysoké škole se vyučuje výhradně na základě badatelské práce. Hlavním úkolem vysokoškolského učitele proto není, aby vyučoval, ale aby ve svém oboru vědecky pracoval. Učitel na univerzitě proto svému předmětu „nevyučuje“, ale veřejně vyslovuje své vědecké názory, jak odpovídá také latinskému slovu profietor. Hessen se kriticky vyjadřruje $\mathrm{k}$ dobové tendenci nahradit univerzitní přednášku učebnicí a vidí v ní úpadek vědeckého ducha univerzity. Pokud má univerzita významný zdroj svého vědeckého pohybu ve studentovi, má umožnit, aby se student soustředil na studium těch oborů, které souvisejí s jeho vědeckým zájmem. To vyžaduje, aby studium bylo založeno na samostatné práci studentů a nebylo prŕliš sešněrováno učebními osnovami a plány, možnost účastnit se studia na jiném katedře nebo fakultě, ba dokonce i volné přecházení mezi fakultami a univerzitami, uznávání zkoušek apod. Zkoušky také nemají být samoúčelné a zkušební zátěž má být snížena na minimum, nebot' požadavkům zkoušky často vyhoví spíš ti, kteří jsou schopni přizpůsobit se cizím požadavkům, než samostatní badatelé (Hessen, 1936, pp. 296-297). Projevem svobody bádání, výuky a studia je také to, že více profesorů může přednášet látku stejného oboru a že studenti mohou vyučující volit (Hessen, 1936, p. 296).

\section{Úplnost studia}

Dalším principem univerzity je úplnost poskytovaného studia. Právě tímto principem, obsaženým ve středověkém pojmu studia generale, $\mathrm{v}$ renesančním universitas scientarium a $\mathrm{v}$ novohumanistickém universitas litterarum, se 
univerzita liší od jiných vysokých škol. Univerzita je tedy Hessenovi stále ještě oním symbolem veškerého vědění, a proto se na ní mají pěstovat, pokud možno, všechny směry bádání. Hessen připomíná, že pouze úplnost vědy odstraňuje jednostrannost, $\mathrm{k}$ níž inklinuje každý specializovaný odborník. Trvá na tom, že vzdělávání má vědecký ráz, jen pokud jsou pěstovány všechny vědy a zároveň jejich vzájemné vztahy (Hessen, 1936, p. 296). Zároveň si ale je vědom toho, že vědění celku, původně zajišt'ované filozofí́, je stále více konfrontováno pluralismem věd a jejich speciálních metod. Věda, která nezná absolutní pravdy, jen hledání pravdy, nutně pokračuje různými cestami (Hessen, 1936, p. 314).

Na jiném místě svého klíčového spisu, $v$ kapitole s názvem Obsah a soustava vědeckého vzdělání, Hessen předkládá svoji vizi vědy jako stromu vědeckého bádání. Kmen vědecké metody, který vyrůstá ze společného kořene poznání, se rozvětvuje na pět větví - přírodovědeckou, matematickou, historickou, filozofickou a filologickou. Tyto větve vyrůstají třemi hlavními směry, směrem matematického poznání exemplární skutečnosti, směrem filologického poznání individuální skutečnosti a směrem dialektického poznání smyslu a struktury hodnot (Hessen, 936, p. 247). Uvedeným směrům pak odpovídají tři metody poznání - metoda vysvětlení, metoda porozumění ${ }^{9}$ a metoda dialektického vystižení (Hessen, 1936, p. 248). Každému druhu metody také odpovídá zvláštní typ vědeckého pojmu - pojem „zákon“, který umožňuje zasadit všechny jemu podřazené exempláře do číselné řady; pojem „individuální“, který zároveň předpokládá celek; pojem „idea“, která pojímá do své plnosti všechny omezené ideje (Hessen, 1936, p. 248). Univerzita již alespoň zčásti prostřednictvím svých fakult odráží tuto diferenciaci věd moderní doby. Jaká univerzitní organizace by tedy odpovídala pokrytí tohoto celku věd?

V návrhu ideálního členění univerzity na fakulty vymezuje Hessen tři teoretické a pět praktických fakult. Mezi fakulty teoretické řadí př́rodovědně-matematickou, historicko-filologickou a filozofickou. K fakultám praktickým technickou, politickou, pedagogickou, právnickou a bohosloveckou. Také klade otázku, zda skutečně veškerý obsah výuky praktických fakult je vhodný pro univerzitu. Vyjadřuje se např́iklad k obsahu výuky na fakultě bohoslovecké. $Z$ něj patří na univerzitu studium náboženství na základě filologické metody, nikoli však např. praktické bohosloví, které je vázáno církevní dogmatikou, která na vědeckou instituci nepatří, nebot' duch vědy nesnese spoutání jinou autoritou, než je autorita vědy samotné (Hessen, 1936, s. 306). Podobně se zamýšlí nad tím (Hessen, 1936, p. 302-303), v jakém smyslu patří do univesritas scientarum technika. Je si vědom, že je čím dál obtížnějši stanovit ostrou hranici mezi čistou vědou a jejím praktickým užitím. Nicméně pokud by technické poznání bylo zaměřeno na zisk a rentabilitu, svoboda jeho bádání by byla omezena, a tím by byl popren

\footnotetext{
${ }^{9} \mathrm{~V}$ otázce porozumění historické skutečnosti vyzdvihuje Hessen př́nos W. Diltheye, ale upírá jeho popisné psychologii jako metodě vcit'ování se do historických událostí její opodstatnění. Tvrdí, že také historické vědy si vystačí s metodou filologickou definovanou Schleiermacherem, nebot' tato metoda (Hessen, 1936, p. 242) dokáže přesně a objektivně vystihnout obsah kulturní skutečnosti logickými pochody diskursivního myšlení. Tím, že podává skrze abstraktní pojmy přssně konstruovaný důkaz, připomíná podle Hessena v mnohém matematiku.
} 
základní princip vědy na univerzitě. Hospodářský zájem nesmí podle Hessena vítězit nad zájmem vědeckým. Na druhou stranu připouští, že zařazením jedné, dvou menších technických fakult na univerzitu nemůže být snížen vědecký duch univerzity (tato argumentace má dnes, v neoliberální době, kdy mají vysoké školy usilovat v rámci své „třetí funkce“ o spolupráci s podnikatelskou sférou a o tržní zhodnocení vědění, př́ichut' nostalgie).

$\mathrm{Z}$ dalších věd, nad nimiž se Hessen $\mathrm{z}$ hlediska úplnosti univerzitního studia zamýšlí, zmiňme ještě pedagogiku. Pedagogika se začala v univerzitním prostředí etablovat jako samostatná věda koncem 19. století. Pro Hessena je jednou $\mathrm{z}$ nejušlechtilejších forem aplikovaného filozofického vědění. $\mathrm{Na}$ jejím rozvoji totiž závisí stav vzdělávání národa, a tedy $\mathrm{v}$ konečném důsledku i úroveň vědecké práce univerzity (Hessen, 1936, p. 304305). Domnívá se proto, že všechny univerzitní obory by měly být obohaceny poznáním pedagogických disciplín (filozofická pedagogika, dějiny a politika národního vzdělávání, didaktiky výuky jednotlivých věd apod.), aby mohly participovat také na nižších vzdělávacích stupních, a tím v konečném důsledku přispěly k rozvoji univerzitní vědy.

Vzhledem k významu pedagogiky by Hessen rád viděl na univerzitě samostatnou pedagogickou fakultu. V době, v níž formuloval Filosofické základy pedagogiky, však byla tato vize ještě př́liš vzdálená praktické realizaci. Proto za nejracionálnější způsob začlenění pedagogiky do univerzity považoval praxi anglických univerzit, kde celouniverzitní pedagogický ústav zajišt’uje zvláštní pedagogický vzdělávací cyklus, který je podle potreby připojován $\mathrm{k}$ cyklům vědeckým. Od Hessenovy doby pedagogika na této cestě postoupila, vznikly pedagogické fakulty a pedagogika je studována jako samostatný vědní obor. Zaplatila však cenu, která by pro Hessena byla stěží prrijatelná. Svým úsilím o scientizaci téměř ztratila vazbu na filozofii, a tím do určité míry i schopnost klást skutečně zásadní obecné otázky.

\section{Autonomie univerzity}

Posledním principem univerzity je její vnitřní i vnější autonomie, také ona plyne $\mathrm{z}$ podstaty univerzity jako ohniska svobodného bádání a vyučování. „Nic neodporuje více ideji univerzity než systém byrokratického spravování a poručnictví státem nebo církví", ř́ká Hessen (1936, p. 311). Vždyt' věda není nástroj státu o blaho občana, to by popřelo vědu v její vnitřní samostatné hodnotě.

Hessen je ve své podstatě sociální myslitel. Velkou inspirací mu byla Natorpova myšlenka kultivované lidskosti, která byla klíčovým argumentem Natorpova „vzdělávacího socialismu“, v němž hospodářství a politika byly považovány za nástroje $\mathrm{k}$ prosazování humanizace a sociální spravedlnosti prostřednictvím vzdělávání, kultivace a civilizace (Matsuda \& Hämäläinen, 2021). V otázce autonomie škol se proto Hessen velmi pochvalně vyjadřuje o Natorpově díle „Socizial-idealismus“, ve kterém podal novokantovskou modifikaci Platónova učení o filozofických králích. Oceňuje, že vzdělání u Natorpa nemá být řízeno státem, ale autonomií ducha, kterou má zaručit ústřední rada duchovní práce složená ze zástupců univerzit, škol, výchovných zařízení, svazů mládeže, vydavatelství, náboženských svazů všech vyznání, 
rodičů aj. Tato rada má nezávisle řídit národní vzdělávání, aby byla započata přestavba státu na základě vzdělání, po které má následovat hospodářská, politicko-právní oblast. Tak má být celý stát spravován odborníky a zároveň účastníky př́slušných složek národního života. To je pravý socialismus, nikoli socialismus masy, ale socialismus vědy a rozumu, ne socialismus mechanicky-politický, ale organicky-korporativní (Hessen, 1936, p. 148). Přesto dodává, že pokud jde o školství, může být autonomně ř́zena pouze univerzita, která jediná je z povahy vědy samé plně svobodná, zatímco $\mathrm{z}$ podstaty nižších škol plyne, že si již povahou své činnosti (úkolová práce) a povahy svého vnitřního řízení (autorita) nemohou činit nárok na autonomii (tamtéž).

Jaký tedy má být vztah univerzitní autonomie a státu? Univerzita je jen potud státní institucí, pokud je uznání státu nezbytné $\mathrm{k}$ tomu, aby se univerzitě dostalo statutu veřejnoprávní instituce. Na univerzitě jako veřejnoprávní instituci vyučují vědci bez ohledu na př́ślušnost politickou, sociální nebo náboženskou (Hessen, 1936, p. 316). Autonomie univerzity pak má být omezena jen natolik, aby se nezvrhla v „libovůli cechu učenců” (Hessen, 1936, p. 315). Celý její vnitřní chod má zajišt'ovat princip univerzitní samosprávy. Avšak samospráva (právo volit profesory a další akademické svobody), je opět pouze prostředkem $\mathrm{k}$ tomu, aby byla zachována svoboda bádání a vyučování, a pouze tato svoboda je také jediným oprávněním univerzitní autonomie (Hessen, 1936, p. 315).

Hessenovy názory na univerzitu měly ve druhé polovině 30 . let výrazné politické konotace. Vždyt' jak protichůdně přistoupil k vymezení ideje univerzity téměř ve stejné době $M$. Heidegger, nástupce E. Husserla na Univerzitě ve Freiburgu. Zatímco pro Hessena má být univerzita prosta státního tlaku, u Heideggera, který se $\mathrm{v}$ určité fázi svého života zapletl $\mathrm{s}$ národním socialismem, je univerzita řízena potřebou vzdělávání národa prostřednictvím státu (Heidegger, 1934). Logicky proto u Heideggera nenalezneme ani slova o autonomii bádání a výuky. Prvotním úkolem univerzity není zkoumat a přitom vyučovat, ale právě naopak, vyučovat, a přitom zkoumat. Vyučovat pak znamená ukazovat, co má význam a co nikoli, zajistit, aby pohled studenta směřoval $\mathrm{k}$ tomu, co je esenciální. Pokud totiž věda nemá hranice, vzniká nebezpečí, že se výuka stane něčím bez cíle (Heidegger, 1934). Toto tvrzení je v naprostém rozporu s neomezeným duchem vědy, za kterým stojí Hessen.

Již v době Kantově se začalo ukazovat, že univerzita není jen chrámem vědy a vědění, ale mocenským kolbištěm, na němž spolu soupeří př́ślušníci jednotlivých fakult. Podle Hessena (Hessen, 1936, p. 314) však na univerzitě jako veřejnoprávní instituci nesmí být žádný vědecký směr utlačován. Věda žije z různotvárnosti svých směrů a jen systém decentralizace a autonomie univerzit je s to zajistit vědecký život před dogmatismem. Tak může každá univerzita tvořit svébytnou kolektivní duchovní individualitu, která ji může odlišovat od jiných univerzit a činit svým duchem neopakovatelnou.

\section{Hessenova idea univerzity dnes?}

Od doby, kdy se Hessen vyjádřil k pojetí univerzity, uběhlo téměř sto let. Dnes žijeme v době vzdalování od univerzitního archetypu. Kritici tohoto 
trendu jako Liessmann (2008, 2015), Readings (1996), Šima a Pabian (2013) se domnívají, že univerzita leží v troskách ideálů, z nichž vyrostla. Co dnes zbývá z její ideální podstaty? Klasické akademické paradigma nedokáže čelit postulátům konkurenceschopnosti, excelence a merkantilizovanému pojetí vysokoškolského vzdělávání. Nová odpovědnost univerzity nespočívá ani tak v závazku vůči reflexivně vytěžené pravdě, jako spíše v tržním zhodnocení vědeckého myšlení (Lorenzová, 2015). Koncept inovací jako strategie řízení vědy ukazuje $\mathrm{k}$ aktuálním potřebám a krátkodobým perspektivám, rychlé rentabilitě a zužitkovatelnosti výsledků vědy i levnému vytěžení lidských zdrojů. Univerzita přejímá logiku „shareholder kapitalismu“ a upřednostňuje krátkodobé zisky na úkor dlouhodobého a promyšleného rozvoje (Stöckelová \& Vostal, 2015).

Úkolem vědy je plodit inovace, protože inovace plodí peníze. Hlasatelé této nové vědecké revoluce žádají, aby „,svět vědy přestal být izolován od sociálního okolí a produkce vědění se stala společensky a ekonomicky odpovědnou“ (Veselý et. al., 2004, p. 41). Vědění, které neobstojí, má být z univerzit odstraněno. Humanitní vědy tak ustupují jako nerentabilní do pozadí a je možné, že budou z univerzity zcela vymýceny (Readings, 1996). Výzkum se stal se záležitostí akademických sítí. Definitivně skončila „éra profesora“ (Lyotard, 1993), výsostného hledače filozoficky legitimované pravdy. Z univerzity se vytrácí svobodný duch vědy, o kterém Hessen v souvislosti s učitelem jako badatelem hovořil. Naproti tomu roste tlak na kvantitu akademické produkce měřené bibliometrickými ukazateli. Nutnost akademického přežití v konkurenčním prostředí demoralizuje samu podstatu vědecké práce, jak ukazují četné mediálně propírané kauzy neetického jednání akademiků. Z diskursu o poslání univerzity vymizel pojem kultury a humanity. Jakými kulturními úkoly, jakými nadčasovými a nadosobními principy se dnes univerzita zaštit'uje? Pokud má být dnešní univerzita především podnikavá, excelentní a internacionalizovaná, nezbývá než doufat, že tento soumrak klasické univerzitní ideje je výzvou pro sovu Minervinu.

\section{Post scriptum: Ohlas Hessenova díla v Československu a ČR}

Pokud se vrátíme ještě jednou k Hessenově předmluvě Filozofických základů pedagogiky, vyjádřil v ní naději, že dílo přispěje $\mathrm{k}$ tomu, aby se $\mathrm{v}$ české pedagogice více prosadily myšlenky, které považuje za správné. To se však nenaplnilo $\mathrm{v}$ takové míře, $\mathrm{v}$ jaké by si autor přál. Ohlas jeho pedagogicko-fillozofického myšlení poznamenal v Českolovensku složitý vývoj Evropy od nástupu diktatury proletariátu v Rusku po zničení iluzí o demokratickém životě v zemích, které zahrnuly velmoci do sféry sovětského vlivu. Proto nalezneme etapy, kdy bylo Hessenovov dílo pochvalně přijímáno, stejně jako etapy, kdy bylo kriticky zavrhováno.

V meziválečném období bylo Hessenovo dílo předními českými pedagogy vysoce ceněno. V Pedagogické encyklopedii, impozantním meziválečném kolektivním díle předních československých akademiků a školských pracovníků, se filozof a pedagog J. Hendrich o Hessenových Filozofických základech výchovy vyjádřil jako jednom z nejlepších děl současné pedagogiky (Hendrich in Chlup, Uher, Kubálek a kol., 1938, p. 470). Toto vysoce pozitivní přijetí Hessenovy pedagogiky souviselo mimo 
jiné $\mathrm{s}$ tím, že $\mathrm{v}$ tehdejší době byla českém prostředí tradice myšlení o vztahu kultury a pedagogiky také rozvíjena (Cach, 1997). Již jsme hovořili o stejném pojetí humanity u Hessena a Masaryka. Také filozof a pedagog F. Drtina zdůraznil propojení kultury $\mathrm{s}$ úkoly vzdělání a otevřel jako nadčasový problém pedagogiky vztah „Weltkultur“" a „Nationalkultur“, který bylo podle něj nutné řešit $\mathrm{v}$ rámci reformy československého školství (Cach, 1997, p. 41). Šlo o stejné téma, které Hessen nastolil v polemice s Ušinského myšlenkami ohledně národního vzdělání.

Velký obrat ve vnímání Hessena nastal v Československu po druhé světové válce, kdy byl jako př́íslušník ruské emigrace $\mathrm{v}$ tehdejší marxistické pedagogice $\mathrm{v}$ lepším případě ignorován, $\mathrm{v}$ horším př́ípadě byl hodnocen výslovně negativně. Trnem $\mathrm{v}$ oku byla jak Hessenova kritika reforem sovětské školy, tak jeho novokantovská idealistická filozofie. V padesátých a šedesátých letech minulého století proto zaznamenáváme výpady proti Hessenovi, některé z nich velmi ostré. Proti Hessenovu novokantovství se vymezil pedagog a představitel tehdejší školské politiky M. Cipro (1959), který odmítl zejména Hessenovu filozofii svobody, která je závislá nikoli na poznání objektivně daných zákonitostí přírody (marxismus), ale na ideálně chápaných hodnotách (novokantovství). Hessenovu filozofii proto Cipro hodnotil jako útěk od skutečnosti do imaginárního světa hodnot (Cipro, 1959, s. 465). Toto nepochopení Hessena plynulo z marxistického chápání hodnot a kultury jako třídně a historicky podmíněné nadstavby ekonomických procesů.

Historik pedagogiky J. Cach vytk1 Hessenovi účelové zkreslení některých skutečností sovětské školy a kriticky poznamenal, že Hessenův kantovský ideál vzdělání byl zábranou všestranněji koncipovaného př́stupu $\mathrm{k}$ problémům pracovní a polytechnické školy (Cach, 1967).

$\mathrm{S}$ pochopením se v poválečném Československu nesetkalo ani Hessenovo pojetí univerzity. K. Vališ, pracovník Výzkumného ústavu pedagogického, ve své stati Pedagogika a politika (Vališ, 1960, p. 15-33) odmítl Hessenovu ideální podstatu univerzity, zejména svobodu výuky a studia a nadtř́íní princip vědy, kterým chtěl Hessen, podobně jako kdysi Humboldt, chránit vědu před politickými a byrokratickými zásahy státu. Hessen jako pedagog kultury chtěl vzděláním zachovat kulturu svobodného světa, mravnost a právní řád, pro Vališe je proto apologetou věčnosti měštáckého řádu, kterému jsou etika a právo hlavními způsoby propagace buržoazního světového názoru. Důsledkem Hessenova podrývání myšlenky diktatury proletariátu a její školské politiky je, že ,někteří př́slušníci inteligence jsou dodnes ochotni považovat kritérium mravní za důležitější, než je kritérium třídně politické, kritérium praxe" (Vališ, 1960, p. 28). Vališ také (ibid., p. 18) obviňuje Hessena z „nenávistné kritiky” sovětského školství a přidává, že od bělogvardějce nelze čekat nic jiného. Se solidnější recepcí Hessenových myšlenek se $\mathrm{v}$ české marxistické pedagogice $\mathrm{v}$ podstatě nesetkáváme a lze říci, že v ní Hessenovo dílo bylo na mnoho let jako inspirační zdroj opuštěno.

Oživení zájmu nastalo až po Listopadu 1989, kdy se odborný zvedl zájem o celou ruskou emigraci v meziválečném Československu. Př́ikladem je např. disertační práce J. Macha (2012) zaměřená na její působení a institucionální základnu kolem Ruské svobodné univerzity. Přesto musíme připustit, že důkladnější zpracování Hessenova odkazu je stále v počátcích. Kromě 
encyklopedických prací z dějin pedagogiky, statí k pedagogice kultury (Cach, 1997) a pedagogice hodnot (Semrád, 2013) je skutečně analytických studií k Hessenovi poskrovnu. Zásadnější rozbor provádějí dvě disestační práce, z kulturně-historického hlediska analyzuje činnost S. Hessena v meziválečném období V. Goněc (2000), z hlediska pedagogického L. Hlavičková (2014), která ho interpretuje v souvislosti s idejemi jeho filozofie výchovy. Z podobného úhlu nahliží Hessena práce L. Slobodové (2018), která navíc zpracovala první důkladný přehled všech jeho děl publikovaných v československém období. Věřme, že trend nového promýšlení Hessenova kulturně-pedagogického a filozofického odkazu se těmito studiemi nevyčerpal a není zdaleka u konce.

\section{Bibliographic references}

Agaev, B.V., Gutorov, V.A.. \& Shirinyants, A.A. (2020). Rozhdeniye idei pravovogo sotsializma: S.I. Gessen Dialog so vremenem 71, pp. 141-151. Doi: 10.21267/AQUILO.2020.71.63614

Cach, J. (1967). Rane sovetsky model marxisticke pedagogiky a socialistickeho skolstvi (K nekterym otazkam vztahu Rijna 1917 a vychovy). Pedagogika (17)5, pp. 521-542. ISSN 0031-3815.

Cach, J. (1997). Existuje jeste pedagogika. na zaklade kultury? Pedagogicka orientace 1, pp. 39-46. ISSN 211-4669.

Cipro, M. (1959). K otazce uvedomelosti v mravni vychove. Pedagogika (9)4, 462-476. ISSN 0031-3815.

Chlup, O., Uher, J., Kubalek, J. \& kol. (1938). Pedagogicka encyklopedie. Praha: Novina.

Dmitrieva, N.A. (2016). Back to Kant, or Forward to Enlightenment: The Particularities and Issues of Russian Neo-Kantianism. Russian Studies in Philosophy (54)5, pp. 378-394.

Dubsky, I. (1993). O ideji univerzity. In Fiala, J. (Ed.). Obnova ideje univerzity. Praha: Univerzita Karlova, pp. 71-80. ISBN 80-7066-785-9.

Fichte, J.G. 1971 [1800]). Pojem vzdelance. Praha: Svoboda.

Gonec, V. (2001). Sergius Hessen a Ceskoslovensko. Brno: Masarykova univerzita. ISBN 80-210-2545-X.

Grebeshev, I. \& Nizhnikov, S. (2016). Sergey Hessen's Philosophy of Education. Proceedings of the 2016 International Conference on Contemporary Education, Social Sciences and Humanities. Paris: Atlantis Press, vol. 74, pp. 1-6. Available at: https://www.atlantispress.com/proceedings/iccessh-16/articles

Heidegger, M. (2001 [1934]). La universidad Alemana. Escuela de Filosofia Universidad ARCIS. Available at: http://www.philosophia.cl/biblioteca/Heidegger/La\%20Universidad\%20Ale mana.pdf

Hessen, S. (1909). Individuelle Kausalitat: Studien zum transzendentalen Empirismus. Berlin: Reither \& Reichard.

Hessen, S.I. (1923). Osnovy pedagogiki. Vvedenie v prikladnuu filosofiu Berlin: Slovo.

Hessen S.I. (1928). Novye agrarnye programmy evropejskih socialisticheskih partij Sovremennye zapiski Kn. XXXVI, pp. 470-491. 
Hessen, S.I. (1927). Novaya programma avstriyskoj sots.-dem. partii i syezd v Lintse. Sovremennye zapiski Kn. XXXIII, pp. 502-522.

Hessen, S.I. (1924-1927). Problema pravovogo socializma (cyklus stati). Sovremennye zapiski Kn. XXII, XXIII, XXVII, XXVIII, XXIX, XXX, XXXI.

Hessen, S.I. (1932). Sovremennyy krizis i pererozhdeniye kapitalizma. Novyy grad, 3, pp.60-71.

Hessen, S.I. (1932). Sovremennyy krizis i pererozhdeniye kapitalizma (okonchaniye). Novyy grad, 4, pp. 21-39,

Hessen, S.I. (1924). Krushenie utopizma. Sovremennye zapiski, Kn. XIX, pp. 277-295.

Hessen, S.I. (1933). Sudba kommunisticheskogo ideala obrazovaniya. Novyy grad, 6, pp. 42-59.

Hessen, S. (1936). Filosoficke zaklady vychovy. Praha: Ceskoslovenska graficka unie.

Hlavickova, L. (204). Ideje, tradice a potencial pedagogiky kultury. Olomouc: Univerzita Palackeho (disertacni prace).

Jaspers, K. (1923). Die Idee der Universitat. Berlin: J. Springer.

Liessmann, K. P. (2008). Teorie nevzdelanost: omyly spolecnosti vedeni. Praha: Academia. ISBN 978-80-200-1677-5.

Liessmann, K. P. (2015). Hodina duchu: praxe nevzdelanosti: polemicky spis. Praha: Academia. ISBN 978-80-200-2530-2.

Lobkowicz, M. (1993). Idea univerzity, pohrbeni nadeje moderniho sveta? In

Fiala, J. (Ed). Obnova ideje univerzity. Praha: Univerzita Karlova, pp. 57-70. ISBN 80-7066-785-9

Lorenzova, J. (2015). Kontexty vzdelavani v postmoderni situaci. Praha: Filozofická fakulta Univerzity Karlovy.

Lorenzova, J. (2017). Vyvoj a soucasny stav socialni pedagogiky v iberoamerickem regionu: pohled za horizont stredni Evropy. Paidagogos 2, pp. 32-64. ISSN 1213-3809. Available at: http://www.paidagogos.net/issues/2017/2/article.php?id=3>

Lyotard, J.-F. (1993). Postmoderni situace. In: LYOTARD, F. O postmodernimu. Praha: Filosoficky ustav AV CR, pp. 95-202. ISBN 807007-047-1.

Mach, J. (2012). Rusti intelektualove v emigraci a jejich institucionalni zakladna v Praze (na modelu Ruske svobodne univerzity a pridruzenych instituci, 1923-1945). Brno: Masarykova univerzita (disertacni prace).

Matsuda, T. \& Hamalainen, J. (2021) Launching Paul Natorp's Sozialpadagogik in Japan in the early twentieth century. History of Education (50)3, pp. 291-312, ISSN DOI:10.1080/0046760X.2020.1826056

Palous, M., Sabatova, A. \& Stern, J. (1993). Gaudeamus igitur. Dokument Charty 77. In Fiala, J. (Ed.). Obnova ideje univerzity. Praha: Univerzita Karlova, pp. 81-94. ISBN 80-7066-785-9.

Petran, J. (1993). Vzdalovani i navraty archetypu. In Fiala, J. (Ed.). Obnova ideje univerzity. Praha: Univerzita Karlova, pp. 95-103. ISBN 80-7066-7859 . 
Readings, B. (1996). The University in Ruins. Cambridge: Harvard University Press. ISBN 9780674929535.

Semrad. J. (2013). Hodnoty a výchova. Pedagogica actualis V. Trnava: Univerzita sv. Cyrila a Metoda, s. 71-81. ISBN 978-80-8 105-517-1.

Slobodova, D. (2018). Filosofie pedagogiky Sergeje Gessena In: Nykl, H. (Ed.). Vybrane kapitoly z ruskeho myslení 20.stoleti. Praha: Karolinum, pp. 101-144. ISBN 9788024638980.

Stockelova, T. \& Vostal, F. (2015). Texty bez ctenaru aneb horecna nehybnost vedy. Akademicky bulletin Akademie ved CR (25)7-8, pp. 28-30. ISSN 1210-9525.

Sima K. \& Pabian P. (2013). Ztraceny Humboldtuv raj. Ideologie jednoty vyzkumu a vyuky ve vysokem skolství. Praha: SLON. ISBN 978-80-7419156-5.

Valis, K. (1960). Pedagogika a politika. K nekterym otazkam vztahu vysokoskolske pedagogiky a politiky. Pedagogika (10)1, pp. 15-33. ISSN 0031-3815.

Vesely, A., Kalous, J. \& Markova, J. (2004). Kultivace vedeni v klicovy faktor produkce. Praha: CESES FVS UK. ISBN 80-254-5050-3.

doc. PhDr. Jitka Lorenzova, Ph.D.

Department of Education and Human Sciences

University of Chemistry and Technology, Prague

Technicka 5

Dejvice

16628 Praha 6

Czech Republic

Email: jitka.lorenzova@vscht.cz 